\title{
Fogarasi Katalin
}

Semmelweis Egyetem

Szaknyelvi Intézet

\section{Fogsérülések megnevezéseinek terminologizáltsági foka fogorvosi-szájsebészeti látleletekben}

\author{
https://doi.org/10.48040/PL.2020.10
}

\begin{abstract}
Fogsérülések leirásában és kórismézésében a látleletek későbbi igazságügyi orvosszakértöi megitéléséhez elengedhetetlen az egyértelmü terminushasználat. Korábbi, fogorvosi és szájsebészeti látleleteken végzett interdiszciplináris vizsgálat (Bán - Patonai - Fogarasi et al., 2018) igazolta, hogy a fogsérülések pontos megnevezése a csont- és lágyrészsérülésekhez képest szignifikánsan több esetben hiányzott a látleletek egyes szerkezeti egységeiböl. Jelen tanulmány célja annak felderitése, hogy milyen terminológiai okokra vezethetö vissza a fenti vizsgálat során talált jelentős statisztikai eltérés. A kutatási kérdések megválaszolására a szerző az idézett tanulmány korpuszában (összesen 28 látleletben) elöforduló, kizárólag fogsérülésekre utaló megnevezések további, részletes terminológiai vizsgálatával tesz kísérletet. A leirások releváns részeinek frazémáit konkordancia-elemzéssel mutatja be, valamint a magyar és latin terminusok megfeleltethetöségét szemlélteti. Az összes sérülés 11,1\%-át képezö fogsérülések megnevezéseinek részletes elemzése olyan terminológiai problémát is felfed, amely akár egy igekötö következetlen használatából eredöen nehezitheti a fogsérülés jellegének pontos megitélését. Elsösorban a fogvesztés és a fog fogmederben való elmozdulásának leirásaiban a megnevezések szinonímiából, poliszémiából és a magyar és latin terminusok közötti ekvivalencia hiányából következö alacsony terminologizáltsági foka okozhat félreértést.
\end{abstract}

Kulcsszavak: diagnózis, fogsérülés, frazéma, látlelet, terminologizáltság foka

\section{Bevezetés}

Sérülések klinikai vagy háziorvosi ellátása esetén a nyomozóhatóság gyakran elrendeli Orvosi látlelet és vélemény kiállítását, ami a hatósági eljárás során akár „szakértői tevékenységgé is minősülhet”, valamint hatósági rendelkezéssel nem járó esetekben a sérült maga is kérheti látlelet kiállítását (Sótonyi, 2011:63). Ugyanez érvényes a fogsérülésekkel kapcsolatos eljárásra is. A sérülést ellátó gyakorló orvosnak a látlelet kiállításakor nézőpontot kell váltania (Fogarasi, 2012-14), és olyan módon kell leírnia a sérüléseket, hogy a hatóság által kirendelt igazságügyi orvosszakértő ezek súlyosságát és keletkezési mechanizmusát a leírásuk alapján rekonstruálni tudja (Fogarasi - Schneider - Bajnóczky, 2014). A bíróság a szakértői vélemény tükrében a büntetőjogi kategóriáknak megfelelően minősíti az elszenvedett sérülést (Fogarasi - Schneider, 2015).

A látleletek kiállítására vonatkozó műfaji szabályokat a jelenleg hatályon kívüli, de még hivatkozási alapul szolgáló módszertani levél (az Országos Igazságügyi Orvostani Intézet 16-os számú módszertani levele) tartalmazza, amely külön kitér a fogsérülések leírásával és véleményezésével kapcsolatos 
tudnivalókra is (Bán et al., 2018). A látlelet (az általános belgyógyászati és idegrendszeri állapot leírásán és a gyógytartam meghatározásán kívül) terminológiai szempontból három fontos szerkezeti egységre osztható: a sérülések részletes leírására (ún. „külsérelmi nyomok”), valamint az ezekhez kapcsolódó magyar és latin nyelvü kórismékre. A kórisméket az orvosi diskurzuson belüli egyértelműség érdekében latinul, a nyomozóhatóság nem orvos résztvevői számára pedig magyar nyelven is meg kell nevezni. A sérüléseknek a külsérelmi nyomok pont alatt történő „,leírásánál az orvosi gyakorlatban használatos, érthetö és utólag elemezhetö magyar kifejezéseket kell használni" (16-os számú módszertani levél).

\section{Fogsérülésekről készült látleletek korábbi vizsgálata}

Terminológiai elemzések korábban történtek baleseti sebészeti és háziorvosi látleletek esetében (Fogarasi, 2012-14), fogorvosi látleletekröl 2018-ban készült az első, orvosszakmai mellett terminológiai szempontokat is figyelembe vevő vizsgálat (Bán et al., 2018). A tanulmány egy $147 \mathrm{db}$ anonimizált fogorvosiszájsebészeti látleletből álló korpuszt vizsgált, amelyek közül 94 db-ot a Pécsi Tudományegyetem, 53-at pedig a Debreceni Orvostudományi Egyetem Fogászati és Szájsebészeti Klinikája bocsátott rendelkezésre a PTE/53707/2017 számú etikai engedély alapján, a 2014 és 2017 közötti időszakból.

A korpusz összesen 352 sérülés leírását tartalmazta, amelyekből 145 lágyrészsérülés, 168 csontsérülés és 39 fogsérülés került ki. Mivel a vizsgálat terminológiai célpontja az összes sérülésre kiterjedt és elsősorban orvosszakmai szempontokat vett figyelembe, a fogsérülések terminológiájának részletekbe menő vizsgálatára nem került sor.

A fent idézett 2018-as tanulmány a fogsérülésekkel kapcsolatban azt a megállapítást tette, hogy a fog törése esetén 5\%-ban nem adták meg, a fog mely része törött. 5 esetben szerepelt ellentmondásos információ egy látleleten belül a sérülések részletes leírása és az egyes leírásokhoz kapcsolódó diagnózis között arra vonatkozóan, hogy mely fog sérült. Csupán 43,6\% utalt a fogazat általános állapotára, ami rendkívül fontos annak megítéléséhez, hogy a sérülés egy már korábban meglazult, rossz rögzítettségü, esetleg kezelt fogat, vagy pedig teljesen ép fogat ért. A természettudományokban elöírt szignifikancia-értékkel számolva szignifikáns $(p<0,05)$ eltérés mutatkozott a fogsérülések és egyéb arc-állcsonti sérülések fogorvosi dokumentációja között abban a tekintetben, hogy mennyire részletesen töltötték ki a látlelet egyes szerkezeti egységeit. Míg az egyéb csontsérülések esetében szinte minden esetben szerepelt adekvát terminus a csontsérülés leírására (1. szerkezeti egység) és az ahhoz kapcsolódó kórismére vonatkozóan (2. és 3. szerkezeti egység), addig a fogsérülések tekintetében igen hiányosan jegyezték fel az adatokat (Bán et al., 2018:2157). 


\section{A tanulmány célja és módszerei}

Mivel a korábbi interdiszciplináris elemzés (Bán et al., 2018) rávilágított, hogy a fogsérülésekre vonatkozó adatokat a fogorvosok szignifikánsan kevésbé alaposan töltik ki a látleletekben, felmerült a kérdés, hogy ennek lehetnek-e terminológiai okai. Mivel a legtöbb esetben a fogsérülések egyéb csontok sérüléseivel is társultak, ugyanazon a látleleten belül is egyértelmü különbség mutatkozott a csontsérülések terminológiailag precíz leírása és kórisméi, valamint a fogsérülések hiányos, sok esetben terminológiailag pontatlan megnevezése között, ami több esetben is megnehezítette a fogsérülés pontos helyének és típusának megállapítását (Bán et al., 2018:2157).

A fenti kérdés megválaszolására jelen vizsgálat az idézett 2018-as tanulmány korpuszának kizárólag fogsérüléseket tartalmazó, összesen 28 látleletből álló alkorpuszának részletes terminológiai elemzésével tesz kísérletet. A fogsérülések részletes leírásainak vizsgálata a WordSmith 7.0 konkordanciaszoftverrel, a kapcsolódó kórisméké manuális módszerrel történt.

\section{Eredmények}

\section{A vizsgált korpusz általános adatai}

Míg az összes fogorvosi látlelet „külsérelmi nyomokban” rögzített részletes sérülésleírásai $95.313 \mathrm{n}$ hosszúságú szöveget tettek ki és 12.232 tokent, valamint 2323 type-ot tartalmaztak, addig a fogsérülések leírásai ennek csupán egyötödét (18.439 n, 2491 token és 938 type) ölelték fel. A type-token arány a fogsérülések esetében $42 \%$ volt, míg a teljes korpuszban csak $20 \%$, tehát a fogsérülések leírásai változatosabbak voltak szókincsüket tekintve a teljes korpuszhoz képest.

\section{A konkordancia-elemzés eredményei}

A fogsérülések alkorpuszában előforduló leggyakoribb kifejezéseket a teljes korpuszon végzett vizsgálat eredményével összevetve az 1. táblázat mutatja be. Mindkét esetben a nem szó volt a leggyakoribb, amely elsősorban a látható igenévvel alkotott kollokációt.

1. táblázat. A fogsérülések leírásaiban használt leggyakoribb kifejezések gyakoriság szerint a teljes korpusz viszonylatában

\begin{tabular}{|c|c|c|c|}
\hline Fogsérülések leírásai & Gyakoriság $(\mathrm{db})$ & Teljes korpusz & Gyakoriság $(\mathrm{db})$ \\
\hline nem & 92 & nem & 451 \\
\hline látható & 36 & bal & 197 \\
\hline bal & 27 & látható & 191 \\
\hline nincs & 25 & jobb & 153 \\
\hline
\end{tabular}




\section{A fogsérülések leírásainak terminológiai elemzése}

Noha a müfaji szabályok a sérülések leírásaiban a magyar nyelvü kifejezések használatát írják elö, fogsérülések esetében a terminusok nyelve korántsem egységes. Az egyes fogsérülések, elváltozások megnevezéseinek vizsgálatakor terminológiai és grammatikai szempontok figyelembevételével öt csoportot különíthetünk el (1. melléklet):

1) latin főnévi terminus kombinációja magyar igével vagy igenévvel, amely érzékelést, történést vagy írásos rögzítést jelent (látható, észlelhetö, diagnosztizálható, látszik, történt, irták le, szenvedett);

2) latin igetőből képzett ige vagy melléknévi igenév (latinos és magyaros helyesírással egyaránt);

3) magyar főnévi terminus kombinációja érzékelést jelentő igével vagy igenévvel (látható, látszik), vagy névszói állítmány (esetenként latin fönévi terminus jelöli a helyet);

4) magyar ige (esetenként latin eredetü terminus szolgál az elváltozás helyének jelölésére);

5) magyar melléknév (esetenként latin eredetü jövevényszó), amely magyar vagy latin fönévi terminusra vonatkozik.

$\mathrm{Az}$ 1. csoport latin föneveinek helyesírása toldalékolás esetén is az eredeti latin formát követi, míg a 2. és 4 . csoport igéi esetében többségben szerepelnek a fonetikus átiratok.

\section{A fogsérülések leírásainak terminológiai jellegzetességei}

Ellentétben a korábbi, baleseti sebészeti látleleteken végzett terminológiai vizsgálatok (Fogarasi, 2012-14; Fogarasi - Schneider - Patonai, 2018) eredményeivel, továbbá a jelen vizsgálat alapkorpuszául szolgáló fogorvosi látleletekben (Bán et al., 2018) szereplő többi, fej-nyaki régiót ért sérülés leírásaival, a fogsérülések leírásaiban elsősorban latin fönevekből vagy igékből képzett, magyarosított igei kifejezések használata volt jellemző pl. frakturált, szubluxálódik, luxálódik, diszlokálódik. A latin terminusok tehát egyértelmüen csak a fogak sérüléseinek megnevezéseiben fordulnak elő.

\section{Megbeszélés}

A fogsérülések leírásai esetében talált type-token arány azt mutatja, hogy az egyéb csontsérülések és lágyrész-sérülések leírásaihoz képest változatosabbak. Ez a stilisztikai szempontból elönyös tulajdonság azonban lehet a terminológiai egységesség hiányának jele is, mivel az elsősorban büntetőjogi célokra szolgáló dokumentáció elsődleges feladata az egyértelmüség, mintsem a stiláris 
változatosság. Különösen, mivel büntetöjogi felhasználásra szánt dokumentumokról van szó, az egyes szakkifejezések jól körülhatárolt fogalmakat írnak le, így a szóhasználat mindenképpen kötött (vö. Fischer, 2018:200), és konkrét terminusok szükségesek.

A szógyakoriságok vizsgálatakor úgy a teljes korpuszban, mint a fogsérülések alkorpuszában a „nem” szó került első helyre, melynek leggyakoribb konkordanciája a "látható" igenév. A sérülések hiányának dokumentációja teljes mértékben megfelel a müfaji szabályoknak, mivel a módszertani levél ezek dokumentációját is elöírja. A „bal” oldal jóval gyakoribb előfordulása vélhetően az elkövetők esetében a jobb kéz dominanciájára vezethetö vissza ${ }^{1}$.

A fogsérülések leírásainak terminológiai elemzése során egyértelmű különbség mutatkozott a fogsérülések és az egyéb sérülések leírásai között mind a jelen tanulmány alapját képező teljes korpuszhoz, mind pedig korábban elemzett baleseti sebészeti látleletekhez viszonyítva. A fogsérülések leírására a legtöbb esetben latinból képzett igealakokat használnak. Míg egyéb sérülések esetében az elváltozást szinte mindig fónévi terminus jelöli egy elliptikus szerkezetben (elváltozás és annak helye létige nélkül vö. Fogarasi, 2012-141:96), addig a fogak sérüléseit általában ige segítségével jelölik.

A fog törését a frakturált (vagy fracturált) befejezett melléknévi igenévvel nevezik meg, amely az igenévi vagy jelen idejü alakban soha nem használt „frakturálni” igéből származik. Ez a szó azonban nem az eredeti latin ige (frango, frangere, fregi, fractum) igei tövéböl jött létre, hanem az abból képzett latin fractura = törés fönévböl képzett denominális verbum. Érdekes megfigyelni, hogy a német szaknyelv hasonló módon képezi a frakturiert befejezett melléknévi igenevet, amelynek az eredeti frakturieren igei alakja az orvosi szaknyelven kívül a kereskedelmi szaknyelvben is ismert. A fog egyes részeinek töréseit a szakirodalom is minden esetben a latin fractura szóval jelöli az érintett fogrész magyar nyelvü megnevezésével pl. korona-gyökérfracturák (Fábián - Gábris - Tarján, 2015:96). A fracturált befejezett melléknévi alak használata a magyar ,eltörött, kitörött, letörött” igealakok helyett nem indokolt a fogak esetében sem, főként, mivel a müfaji szabályok magyar kifejezések használatát határozzák meg a leírásokban.

Igen feltünő a fogsérülések leírásaiban más idegen eredetủ szavak (pl. a passzív jelentésü luxálódott és diszlokálódott alakok) használata is. A fogsérülések szakirodalmát áttekintve azonban érthetővé válik, miért hiányoznak a gyakorlatban a magyar kifejezések. A luxatio kilazulást, kimozdulást jelent (Bakos, 2013), amelyet a baleseti sebészet ízületi sérülések esetén ficamként fordít magyarra. Ficam esetén az ízületi fej teljesen elhagyja a vápát (Gaál, 2012). Fogsérülések esetén ellenben - mivel anatómiai értelemben a fog is egyfajta ízület, amely ugyan folyamatos és nem mozgatható összeköttetés (Szentágothai

\footnotetext{
${ }^{1}$ E kiegészítésért Dr. Patonai Zoltánnak tartozom köszönettel.
} 
- Réthelyi, 2006) - a luxatio azt jelenti, hogy a fog elmozdul eredeti helyzetéböl (Joób-Fancsaly, 2017), ficamként azonban nem fordítható. Ugyanezt a sérüléstípust más szakirodalom luxatio partialis-nak, „a fog részleges kimozdulásának" nevezi (Fábián - Gábris - Tarján, 2015:96), utóbbi kifejezés azonban a korpuszban nem fordult elő. A diszlokálódott ige feltehetően a luxatio mint ficam angolszász terminológiából vett megfelelője, a magyar traumatológiai terminológiában azonban a törött csontvégek elmozdulására használatos (Gaál, 2012). A fog fogmederben történő elmozdulását az angolszász terminológia is luxation-nek nevezi (DiAngelis et al., 2012). A subluxatio terminushoz, amit a baleseti sebészet részleges ficamként értelmez (Gaál, 2012) a fogorvostudományban „, a fog elmozdulás nélkül lazul meg” (Fábián - Gábris Tarján, 2015:96) definíció társul, máshol pedig a fog lazulásaként írják le a fog helyzetének megváltozása nélkül (Joób-Fancsaly, 2017). Ezzel szemben azt az állapotot, amikor a fog kikerül a fogmederböl, avulsiónak /luxatio totalis-nak nevezzük (Joób-Fancsaly, 2017), illetve a „fog teljes kimozdulása az alveolusból" meghatározás is szerepel (Fábián - Gábris - Tarján, 2015:96). Fogak esetén a fent kifejtett anatómiai okok miatt a szabadon mozgó ízületeknél használt amputáció nem fordul elő a fogmeder teljes elhagyásának megnevezésére.

Terminológiai szempontból nem egyértelmü a fog helyzetének meghatározása a magyar elmozdult és kimozdult múlt idejü igékkel, ami a korábbi statisztikai vizsgálatok kivitelezését is nehezítette. Noha a fenti definíció alapján a fogmederből történő teljes kimozdulás jelentené a fog traumás elvesztését, a fogmederben való elmozdulás pedig a luxatiót, egyes szakirodalmi osztályozások a teljes luxatiót is a fog teljes elmozdulásaként írják le (Pinke, 2011). Egyidejüleg másutt a kimozdulás kifejezés is használatos a luxatióra (Szántó, 2014). E kifejezések értelmezése abban az esetben jelentett nehézséget, ha egy látlelet különböző szerkezeti egységein belül nem volt következetes és megfelelö kontextussal támogatott ugyanazon elváltozás megnevezése. Egy esetben például a leírás totalis luxatiót, vagyis fogvesztést tartalmazott, ugyanakkor a kórismék között ugyanerre a sérülésre csupán luxatióként, a fogmederben való elmozdulásként utaltak vissza.

Egy másik esetben ugyanazon látlelet mindhárom vizsgált szerkezeti egysége eltérő terminussal hivatkozott ugyanarra a fogsérülésre, így értelmezhetetlen volt, milyen súlyos fogsérülés történt (2. táblázat).

2. táblázat. Példa egy látleleten belül ugyanazon fogsérülés eltérő megnevezéseire

\begin{tabular}{|l|c|l|}
\hline \multicolumn{1}{|c|}{ Leírás } & Magyar kórisme & Latin kórisme \\
\hline „11 foga az alveolusból kimozdult. & 11,21 fogak & Lux. dent. \\
21 subluxalódott.” & elvesztése & 11,21 \\
\hline
\end{tabular}


A 2. táblázatban feltüntetett példában a leírás a jobb felső nagymetsző fog fogmederből való kimozdulását, valamint a bal felső nagymetsző meglazulását a fog helyzetének megváltozása nélkül tartalmazza. Ugyanezeket a sérüléseket a magyar kórisme mindkét fog elvesztéseként, a kórisme latin fordítása pedig mindkét fog eredeti helyzetéböl való elmozdulásaként adja meg, utóbbi azonban a magyar kórismével ellentétben nem jelenti a fogmeder elhagyását. Mivel a fogvesztés tényének büntetöjogi következménye lehet, ilyen terminológiai következetlenségek jelentősen megnehezíthetik a sérülések igazságügyi szakértői megítélését, valamint a nyomozóhatóság munkáját.

Mivel a fogak sérüléseinek leírásakor egyéb testi sérülések leírásával ellentétben nem helyhatározói megjelölést alkalmaznak, hanem az egyes fogak számosított megjelöléseit, ezért az egyéb sérülések esetében használt elliptikus, nominális leírási mód kevésbé alkalmazható. A fog megjelölése mellé tehát mindenképpen ige (pl. a fog teljesen kimozdult a fogmederböl) vagy birtokviszony (pl. a fog traumás elvesztése) tartozik, amelyeknek egyrészt müfajilag, másrészt jelentésben is alkalmasnak kell lenniük. A müfaji alkalmasság feltétele az objektivitás, vagyis, hogy a leíró kifejezés nem implikálhatja a sérülést ellátó orvos feltételezését a keletkezés körülményeit illetően, hanem arra majd a sérülés morfológiájából és helyéből az igazságügyi orvos szakértő a leírás alapján következtet. Ezért a fogvesztés leírására a kiütötték és kiesett igék nem alkalmazhatóak, valamint jelentéséből eredően az etimológiailag kapcsolható *elveszett ige sem. A hiányzik ige tartós foghiány állapotát is sugallhatja, ami sérülés esetén szintén félrevezetö lehet. Az elmozdul és kimozdul igekötős igék az igekötők fentebb kifejtett, nem egyértelmü jelentésmegkülönböztető szerepéből adódóan csak a teljes/teljesen jelzős vagy határozói szerkezetben válnak pontossá. Ugyanez érvényes a latin luxatio kifejezésre is. Egyértelmüvé teszi azonban a fogvesztést az üres fogmeder (alveolus) feltüntetése. A fogvesztés látleleti leírására a vizsgált alkorpuszban talált és további lehetséges kifejezések müfaji és terminológiai alkalmasságát a 2 . melléklet foglalja össze.

\section{Összegzés}

A terminologizáció folyamata többnyire az általános nyelvi kifejezések terminussá válásával írható le, amelynek sok esetben poliszémia az eredménye (Fluck, 1996:50). A fogak sérülései esetében ez a folyamat feltehetően a már meglévő orvosi szaknyelvből indult ki, és eredményez poliszém terminusokat. A poliszémia egy szakterület terminológiáján belül Wüster terminológiatana alapján nem volt megengedett, jelenléte azonban a terminologizációs folyamat következtében elkerülhetetlen (Fischer, 2018:198). A fogak anatómiai adottságaiknál fogva hasonlóak ugyan az egyéb csontokhoz és ízületekhez, de mivel valójában sok tekintetben el is térnek tölük, a baleseti sebészetben 
alkalmazott fogalmakhoz sorolt terminusok a fogak esetében külön meghatározást igényelnek.

A magyar nyelvü szakirodalom nem egységes azonban az egyes fogsérülések magyar és latin nyelvü megnevezéseit és azok definícióit illetően. Ugyancsak nehezíti a fogsérülések leírását az a körülmény, hogy a fogalmak ekvivalencia-hiánya miatt a latin terminusok nem fordíthatók azokkal a megfelelökkel magyarra, mint a baleseti sebészeti jelentésük esetén (pl. a luxatio és subluxatio terminusok magyar ficam és részleges ficam megfelelöi fogak esetében nem értelmezhetők, ahogy a kapcsolódó *kificamodott ige sem). Noha a látleleti müfaji szabályok megkövetelik a magyar nyelvü terminusok használatát, adekvát magyar megfelelők bizonyos esetekben nem állnak rendelkezésre.

A terminologizáltság szintjeit általában a definícióval ellátott, szigorúan véve egyértelmü vagy ,egyegyértelmü” (Wüster, 1974; Arntz - Picht - Schmitz, 2014:116) szakkifejezések megléte alapján vizsgálhatjuk egy adott szakterületen. Ez alapján megkülönböztethetünk szabványosított, nem szabványosított, gyakorlatban bejáratott és nem bejáratott kifejezéseket (Felber - Schaeder, 1999:1733; Muráth, 2002:84). A fogak töréseivel kapcsolatos terminusok megfelelően definiáltak. A terminológiai elemzés során a vizsgált alkorpuszban elsősorban a fogvesztéssel és a fognak a fogmederben való elmozdulásával kapcsolatos bejáratott és nem bejáratott leírási módok voltak félreérthetök. Több, a gyakorlatban bejáratott kifejezésről derült ki, hogy jelentése egyéb jellemzők megjelölése nélkül nem határozható meg egyértelmüen. A kimozdulás és az elmozdulás önmagában való szinonim használata rendkívüli félreértésekhez vezethet, amelyek elkerülése a látlelet büntetöjogi szerepe miatt kiemelkedően fontos lenne. A fogsérülések dokumentációjával kapcsolatban tehát számos olyan probléma volt feltárható, amelyek más tudományterületek esetében is ellentmondásokhoz vezetnek a kommunikáció során, így az interdiszciplináris együttműködésben egységes terminológiai rendszer kerülne kialakításra (Fóris, 2007). A büntetőjogi céloknak megfelelö, egyértelmü kommunikációhoz szükséges lenne, hogy a szakma képviselőinek részvételével összehangolt magyar és latin terminusrendszer szülessen a fogak sérüléseinek pontos és egyértelmü megnevezésére. Jelen tanulmány kísérletet tett a fogvesztés megnevezésére alkalmas, terminológiai szempontból elfogadható kifejezések összefoglalására.

\section{Hivatkozások}

Az Országos Igazságügyi Orvostani Intézet 16-os számú módszertani levele. Online elérhető: http://semmelweis.hu/igazsagugy/files/2012/06/16 mszlev.pdf

Arntz, R. - Picht, H. - Schmitz, K.-D. (2014): Einführung in die Terminologiearbeit. Georg Olms Verlag: Hildesheim-Zürich-New York

Bakos, F. (2007) Idegen szavak és kifejezések szótára. Akadémiai Kiadó: Budapest 
Bán, Á. - Patonai, Z. - Fogarasi, K. -Schneider, P. - Boda, R. - Gergely, P. (2018): Fogászati sérülésekről készült látleletek komplex terminológiai, fogászati és igazságügyi orvosszakértői elemzése. Orvosi Hetilap. 159. 2154-2161. DOI: https://doi.org/10.1556/650.2018.31212

DiAngelis, A.J. - Andreasen, J.O. - Ebeleseder, K.A. et al. (2012): Guidelines for the Management of Traumatic Dental Injuries: 1. Fractures and Luxations of Permanent Teeth. Dent. Traumatol. 28/1. 2-12. DOI: https://doi.org/10.1111/j.16009657.2011.01103.x

Fábián, G. - Gábris, K. -Tarján, I. (2015): Gyermekfogászat, fogszabályozás és állcsontortopédia. Semmelweis: Budapest

Felber H. - Schaeder B. (1999): Typologie der Fachwörterbücher. In: Hoffmann L, Kalvenkämper H, Wiegand HE. (ed): Fachsprachen: ein internationales Handbuch zur Fachsprachenforschung und Terminologiewissenschaft $=$ Languages for special purposes. Bd. 14. Berlin/ New York: de Gruyter. 1725-1743

Fischer, M. (2018): Terminológiai tévhitek. In: Fischer, M. (2018): Terminológia és fordítás. Válogatott terminológiaelméleti és fordítástudományi tanulmányok. Institutio: Pécs

Fluck, H. R. (1996): Fachsprache. Einführung und Bibliographie. (jew. neueste Auflage). A. Francke Verlag: Tübingen und Basel

Fogarasi, K. (2012-2014): Limited Forensic Assessability of Soft Tissue Injuries: Contrasive Terminological Analyses of Hungarian, Austrian and German Medical Diagnostic Reports. PhD disszertáció. PTE Egészségtudományi Kar: Pécs

Fogarasi, K. - Schneider, P. - Patonai, Z. (2019): Die Rolle von Diagnosen im medizinischen Fachsprachenunterricht: Eine interdisziplinäre Analyse deutscher, österreichischer und ungarischer klinischer Diagnosen. In: Polona, Vičič; Nataša, Gajšt; Alenka, Plos (szerk.) 10th International Language Conference on The Importance of Learning Professional Foreign Languages for Communication between Cultures: Conference Proceedings. Online kiadás, Nemzetközi: E-publication. 107-120. DOI: https://doi.org/10.18690/978961-286-252-7.9

Fogarasi, K - Schneider, P. - Bajnóczky, I. (2014): Helyes szakkifejezéseket tartalmazó látleletek jelentősége a büntetőeljárásban. Magyar Orvosi Nyelv. 14. 78-81

Fogarasi, K. - Schneider, P. (2016): How the Incorrect Use of a Medical Genre and Terminology can result in Erroneous Legal Judgements. CASALC Review. 5: 121-133

Fóris, Á. (2007): A terminusok és a terminológiai rendszer. In: Heltai, P. (szerk.) Nyelvi modernizáció. Szaknyelv, fordítás, terminológia. A XVI. MANYE Kongresszus elöadásai. MANYE-Szent István Egyetem: Pécs-Gödöllő. 15-26

Gaál, Cs. (2012): Sebészet. Medicina: Budapest. Online elérhető: https://www.tankonyvtar.hu/hu/tartalom/tamop425/2011_0001_524_Sebeszet/index.htm $\underline{1}$

Joób-Fancsaly, Á. (2017): Dentoalveoláris traumatológia. A fogak, lágyrészek sérüléseinek fajtái, ellátásuk alapelvei. A fogvisszaültetés klinikuma: indikáció, technika, prognózis. Online elérhető: http://semmelweis.hu/szajsebeszet/files/2017/06/Fogak-balesetis\%C3\%A9r\%C3\%BCl\%C3\%A9sei.pdf

Muráth, J. (2002) Zweisprachige Lexikographie. Nemzeti Tankönyvkiadó: Budapest

Pinke, I. (2011) A fog baleseti sérülései. In: Vályi, P. (szerk.) (2011) Dentálhigiénikusok kézikönyve. Digitális tankönyvtár, Szegedi Tudományegyetem: Szeged. Online elérhető: https://www.tankonyvtar.hu/en/tartalom/tamop412A/2011-0032 magyar/ch02s11.html

Sótonyi, P. (2011): Igazságügyi orvostan. Semmelweis: Budapest

Szántó, I. (2014): Traumás sérülések tejfogazatban. In: TÁMOP: A magyarországi fogorvosképzés módszertani és tartalmi modernizációja korszerü hosszanti digitális tananyagfejlesztéssel három nyelven. Dialóg Campus Kiadó - Nordex Kft. Pécsi Tudományegyetem; Semmelweis Egyetem: Pécs - Budapest. Online elérhető: 
https://www.tankonyvtar.hu/hu/tartalom/tamop412A/2011-

0095 fogaszat magyar/ch02s03.html

Szentágothai, J. - Réthelyi, M. (2006): Funkcionális anatómia I. Medicina: Budapest Online elérhetö:

https://www.tankonyvtar.hu/hu/tartalom/tamop425/2011_0001_524_Funkcionalis_anato mia 1/adatok.html

Wüster, E. (1974): Die allgemeine Terminologielehre - ein Grenzgebiet zwischen Sprachwissenschaft, Logik, Ontologie, Informatik und den Sachwissenschaften. In: Laurén, C. -Picht, H. (ed.) (1993): Ausgewählte Texte zur Terminologie. TermNet Internat: Wien. 331-376. DOI: https://doi.org/10.1515/ling.1974.12.119.61 
1. melléklet. A fogsérülések megnevezésére használt szakkifejezések osztályozása terminológiai és grammatikai szempontok alapján

\begin{tabular}{|c|c|c|c|c|}
\hline 1) Latin fónév + magyar ige & $\begin{array}{l}\text { 2) Latinból képzett ige vagy } \\
\text { igenév }\end{array}$ & $\begin{array}{l}\text { 3) Magyar fónév (+ ige, } \\
\text { névszói állítmány) }\end{array}$ & 4) Magyar ige & 5) Magyar melléknév \\
\hline $\begin{array}{l}\text { - } \text { alveolaris infractióját } \\
\text { - } \text { caries profunda } \\
\text { - } \text { élfractura } \\
\text { - } \text { fractura coronae dentis } \\
\text { non complicata } \\
\text { - } \text { fracturae coronae dentis } \\
\text { - } \text { az incisalis harmadban } \\
\text { - fracturája } \\
\text { - } \text { gyökérfraktúrát } \\
\text { - } \text { komplikált koronai } \\
\text { - fractura } \\
\text { - } \text { luxatiója volt látható } \\
\text { - } \text { pulpaexpositio } \\
\text { - } \text { radicis relictae } \\
\text { - radix } \\
\text { - radix } \\
\text { - totalis luxatiója } \\
\text { - totális luxatioja } \\
\text { - zománc-dentinfractura }\end{array}$ & $\begin{array}{l}\text { - } \text { diszlokálódtak } \\
\text { - fracturáltak } \\
\text { - frakturált } \\
\text { - gingiva szél alá frakturált } \\
\text { - laterálisan luxálódtak } \\
\text { - } \text { subluxálódott } \\
\text { - totálisan luxálódott }\end{array}$ & $\begin{array}{l}\text { - } \text { sérülése nem a baleset } \\
\text { - } \text { következménye } \\
\text { - } \text { sulcusából vér } \\
\text { - törés } \\
\text { - zománc törés } \\
\text { - zománcrepedés }\end{array}$ & $\begin{array}{l}\text { - } \quad \text { a beteg fájlalja } \\
\text { - } \text { alveolust teljesen } \\
\text { - } \text { elhagyta } \\
\text { - } \quad \text { az alveolusból kimozdult } \\
\text { - } \quad \text { éle lepattant } \\
\text { - } \quad \text { kitörtek } \\
\text { - letörtek } \\
\text { - } \text { mozdult ki az okklúziós } \\
\text { síkból labiális és } \\
\text { - } \text { okklúziós irányban } \\
\text { - } \quad \text { sérültt mega megnyílt } \\
\text { - } \quad \text { tört ki }\end{array}$ & $\begin{array}{l}\text { - } \text { alveolus üres } \\
\text { - } \text { egy blokkban } \\
\text { mozgathatóak } \\
\text { - érintésre érzékeny } \\
\text { - kopogtatásra érzékeny } \\
\text { - mobilisak } \\
\text { - prognózisa erősen } \\
\text { - kérdéses } \\
\text { - vitalitás pozitív }\end{array}$ \\
\hline
\end{tabular}


2. melléklet. A fogvesztés látleleti leírására a vizsgált alkorpuszban talált és további lehetséges kifejezések müfaji és terminológiai alkalmassága (a terminológiai szempontból javasolt kifejezések kövér betütípussal kerültek kiemelésre)

\begin{tabular}{|c|c|c|c|c|}
\hline $\begin{array}{c}\text { Müfaji } \\
\text { alkalmasság }\end{array}$ & Jelentésbeli alkalmasság & Főneves szerkezet & Igei szerkezet & Mellékneves szerkezet \\
\hline+ & - & *x fog ficama & $*_{x}$ fog kificamodott & \\
\hline- & - (tartós állapot) & foghiány & $\mathrm{x}$ fog hiányzik & \\
\hline (nem objektív) & + & & $\mathrm{x}$ fog kiesett & \\
\hline (nem objektív) & + & & $\mathrm{x}$ fogat kiütötték & \\
\hline+ & + & x fog elvesztése/ avulsiója & $\begin{array}{l}* x \text { fog elveszett } \\
* x \text { fog kiszakadt }\end{array}$ & \\
\hline+ & + & & & $\begin{array}{l}\text { üres alveolus } \\
\text { (fogmeder) }\end{array}$ \\
\hline+ & - $\quad$ (helyzetváltoztatás, mobilitás?) & $\mathrm{x}$ fog elmozdulása & $\mathrm{x}$ fog elmozdult & \\
\hline+ & $\begin{array}{c}\text { ? (helyzet/helyváltoztatás?, } \\
\text { mobilitás?) }\end{array}$ & $\begin{array}{c}\mathrm{x} \text { fog } \frac{\text { teljes kimozdulása } \mathrm{az}}{\text { alveolusból }} \\
\end{array}$ & $\begin{array}{c}\mathrm{x} \text { fog teljesen kimozdult } \mathrm{az} \\
\text { alveolusból }\end{array}$ & \\
\hline+ & + & & $\begin{array}{c}\text { x fog az alveolust teljesen } \\
\text { elhagyta }\end{array}$ & \\
\hline+ & + & x fog teljes luxatiója & x fog teljesen luxálódott & \\
\hline
\end{tabular}

